\title{
Substrate and Enzyme Characteristics that Limit Cellulose Hydrolysis
}

\author{
Shawn D. Mansfield, † Caitriona Mooney, ${ }^{\ddagger}$ and J ohn N. Saddler*,‡
}

PAPRO, New Zealand F orest Research Limited, Sala Street, Private Bag 3020, Rotorua, New Zealand, and Forest Products Biotechnology, Department of Wood Science, $4^{\text {th }}$ Floor, F orest Science Centre, 4042-2424 Main Mall, University of British Columbia, Vancouver, B.C., Canada

\begin{abstract}
The ability and, consequently, the limitations of various microbial enzyme systems to completely hydrolyze the structural polysaccharides of plant cell walls has been the focus of an enormous amount of research over the years. As more and more of these extracellular enzymatic systems are being identified and characterized, clear similarities and differences are being elucidated. Although much has been learned concerning the structures, kinetics, catalytic action, and interactions of enzymes and their substrates, no single mechanism of total lignocellulosic saccharification has been established. The heterogeneous nature of the supramolecular structures of naturally occurring lignocellulosic matrices make it difficult to fully understand the interactions that occur between enzyme complexes and these substrates. However, it is apparent that the efficacy of enzymatic complexes to hydrolyze these substrates is inextricably linked to the innate structural characteristics of the substrate and/or the modifications that occur as saccharification proceeds. This present review is not intended to conclusively answer what factors control polysaccharide biodegradation, but to serve as an overview illustrating some of the potential enzymatic and structural limitations that invariably influence the complete hydrolysis of lignocellulosic polysaccharides.
\end{abstract}

\section{Introduction}

Despite the extensive amount of research undertaken over the last few decades, our understanding of how enzymes completely hydrolyze lignocellulosic substrates is still far from comprehensive or complete. Past work has indicated the complexity of the substrate and the need for many different enzymes before these substrates can be effectively and completely hydrolyzed. However, the deceptive simplicity of the repeating $\beta-1-4$ linking cellobiose unit is not indicative of the complex arrangement of the substrate at the fibril, fiber, and wood/pulp levels. Similarly, although tools such as molecular biology and protein engineering have helped elucidate the role of some of the enzymes in the synergistic attack of lignocellulosic substrates, our understanding of basic mechanisms such as enzyme regulation, kinetics, and the extent of true synergism is still lacking. As a result, an important aspect of much of the research to date has been to ascertain the limiting factors involved in the decreased hydrolysis rate as time progresses. These factors have traditionally been divided into two groups: those which rel ate to the structure of the substrate and those related to the mechanisms and interactions of the cellulase enzymes.

Various model cellulose substrates have been used for the purpose of studying the mechanism of action and interaction of individual cellulase enzymes and the effect of substrate characteristics, such as degree of polymerization and crystallinity, on the rate and efficiency of

\footnotetext{
* Corresponding Author.

† New Zealand Forest Research Limited.

₹ Forest Science Centre.
}

enzymatic hydrolysis. These include Avicel, solka floc, filter paper, cotton, valonia cellulose, phosphoric acid swollen cellulose, bacterial microcrystalline cellulose (BMCC) and soluble cellulose derivatives (17, 18, 6567, 115-116, 152, 159, 173-175, 188, 190, 191, 197). While many of these relatively "pure" cellulosic substrates have been of immense importance in determining the role that these substrate characteristics play in hydrolysis, they have al so presented additional questions. Do these enzymes act in a similar manner on heterogeneous substrates, such as plant biomass and/or wood? Does the presence of other compositional constituents influence the cellulolytic mechanism of enzymatic degradation, and are other "multifunctional" enzymes required to act in concert with the cellulase enzymes to achieve the total saccharification? While it is well recognized that cellulase monocomponents act synergistically, is there a similar synergistic relationship between different hydrolases during the saccharification of a heterogeneous lignocellulosic substrate?

Both the size and mode of action of hydrolytic enzymes influence their degradative capabilities, with the majority of structural modifications occurring at the substrate surfaces. How then is it possible for these relatively large enzymes to penetrate into highly ordered cellul ose and disrupt the integrity of the ultrastructure? Does "amorphogenesis" really occur and does an enzyme component such as the originally suggested $C_{1}$ cellulase really exist? Have we, the "students of cellulases", simply accepted the proposed hypothesis of monocomponent synergism and abandoned the search for contributing components of cellulose degradation? Could oxidoreductases, such as cellobiose dehydrogenase, which have been deemed "enzymes in search of a function" (108), actually be associ- 
ated with cellulose degradation? I n this paper we do not attempt to directly answer these questions, but rather indicate that, while many questions have been answered, past work has brought new and interesting questions to the forefront of lignocellulosic saccharification. These unresolved issues consequently warrant further consideration.

\section{Background}

There have been three noticeable periods of "enlightenment" in our understanding of the role of cellulases in the modification and degradation of lignocellulosics. In the 1950s the pioneering work of Reese and Mandels showed the importance of fungi in degrading cellulose, bringing the genus Trichoderma to preeminence because of the "aggressiveness" of their cellulases. These workers first introduced the $\mathrm{C}_{1}-\mathrm{C}_{\mathrm{x}}$ concept to try to explain how the cellulase system first "opened-up" the cellulose matrix $\left(C_{1}\right)$ while the more accessible substrate could then be hydrolyzed by the $C_{x}$ components $(98,135,137)$. The second period of enlightenment showed that, although endoglucanases could act in much the same way as the proposed $C_{x}$ cellulases, exoglucanases did not fill the role of a $\mathrm{C}_{1}$ cellulase as it appeared that they attacked the cell lul ose from the nonreducing end to liberate cel lobiose (196). It was subsequently shown that some exoglucanases could also attack from the reducing end. Despite our inability to find an enzyme which could induce "amorphogenesis" to a cellulosic substrate, the proposed synergistic $\mathrm{C}_{1}-\mathrm{C}_{\mathrm{X}}$ interaction model was adapted to suggest an endo-exo interaction that results in more than just the additive interaction of the component cellulases $(28,29,62,196)$.

In the last 10 years the tools of molecular biol ogy have allowed us to determine the amino acid sequence, crystallography, and three-dimensional structure of the various cellulase and xylanase enzymes. Rather than classifying these enzymes on the basis of their proposed endoor exo- action, this most recent period of enlightenment has grouped cellulase/xylanases on the degree of homology of their binding and catalytic domains (176). Those cellulases exhibiting an exoglucanase mode of action generally have a "tunnel"-shaped structure, while the more randomly acting endoglucanases have a more "cleft"-shaped catalytic domain (180).

Despite these considerable advances in our understanding of cellulase structure-function, we have still not resolved why there is a need for such a multiplicity of "cellulases". Moreover, we have not determined the changes that occur to the lignocellulosic structure at the fiber, fibril, or elementary microfibril levels. Although a substantial amount of research has been directed at understanding the mechanism(s) of cellulose degradation, the majority of this research has made use of "ideal" model substrates.

While these efforts have contributed significantly to our understanding of cellulose saccharification, translating this information to explain the degradation of naturally occurring lignocellulosic has proven an arduous task. For example, it is generally recognized that the traditional endo/exo synergistic model of cellulose degradation may be an oversimplification when considering cellulose degradation of a heterogeneous substrate containing cellulose, hemicellulose, and lignin. It is likely that other synergistic cooperations must be taken into consideration, such as the relationship between xylanases and cellulases, when considering the degradation or modification of lignocellulosic substrates.
Since its inception, a considerable amount of work has been done to elucidate and expand on the $\mathrm{C}_{1}-\mathrm{C}_{\mathrm{X}}$ mechanisms of cellulose hydrolysis (27-31, 56, 175, 188, 190, $192,193,195,197)$. Although various hypotheses concerning the mechanisms of the individual cellulase components have been devel oped $(61,176,180,196)$, a general mechanism which includes the action of all microbial cellulases (and other enzymes) has not been firmly established. However, it is generally accepted that the conversion of native cellul ose to glucose requires three different types of enzymes. These include a $\beta$-1-4endoglucanase (endoglucanase, EC 3.2.1.4), a $\beta$-1-4exoglucanase (cellobiohydrolase, EC 3.2.1.91), and a $\beta$-glucosidase (cellobiase, EC 3.2.1.21). Each one of these components may be glycosylated and may exist in multiple forms, and each enzyme seems to have a distinct range of activities on different cellul osic substrates. Other researchers have suggested that additional enzymes such as glucohydrolases (134) and cellobiose dehydrogenase $(3,8,64,85,99)$ may also play a role in cellulose degradation.

Our current understanding of enzyme-mediated hydrolysis of native cellulose by extracellular microbial enzyme systems primarily results from the synergistic interaction of $\beta$-1-4-endoglucanases and $\beta$-1-4-exoglucanases (cellobiohydrolase) to yield cellobiose that is subsequently cleaved to glucose by $\beta$-glucosidase (193, 196). The endoglucanases (EGs) act randomly to hydrolyze amorphous cellulose and soluble derivatives of cellulose (40). This reaction involves the cleavage of $\beta$ - 1 4-glycosidic bonds with little release of reducing sugars. In contrast, cellobiohydrolases (CBHs), which were initially thought to remove cell obiose residues consecutively from the nonreducing end of the cellulose chain, have more recently been shown to attack the cellulose from both the reducing and the nonreducing ends of the cellulose chain $(66,127,128,180)$. Finally, $\beta$-glucosidases complete the hydrolytic process by catalyzing the hydrolysis of cellobiose residues to glucose, or by removing glucosyl residues from the nonreducing end of the soluble cellooligosaccharides. Although these definitions are still generally used to group cellulases, recent studies have indicated that the substrate specificities of the various endoglucanases and cell obiohydrolases are considerably more complicated than this oversimplified classification (19-21, 146).

Typically, amorphous cellulose has been reported to be rapidly degraded to cellobiose, while the hydrolysis of crystalline cellulose is slower, and the rate depends on the degree of polymerization and the crystal linity of the cellulose $(55,118,189,197)$. The theory proposed by investigators such as Wood and McCrae (196) was that neither endoglucanases nor exoglucanases acting al one could effect extensive hydrolysis of crystalline cellulose. However, when acting together, the exoglucanases removed cellobiose units from the chain ends provided by the random cleavage of glycosidic linkages by the endoglucanases. The resulting cellobiose units were then degraded to glucose by the $\beta$-glucosidase. An extensive investigation into the synergistic action of cellulases by Wood et al. (192, 194, 197) using various purified components of the cellulase system of Penicillium pinophilum indicated that multiple forms of the individual components are required in order to initiate extensive cellulose hydrolysis. Thus, the individual isocomponents are believed to have an apparent duplication of function (40). More recently there have been examples of exoexo- (113) and endo-endo-type $(102,103)$ synergistic cooperation among cellulases. 
The existence of multiple isocomponents exhibiting duplication of function supports a mechanism of the synergistic action based on the steric considerations resulting from the cleavage of the repeating $\beta-1-4-$ glycosidic linkages found within the cellulose chains. Therefore, there are two fundamental mechanisms by which glycosidases cleave a $\beta$-1-4-glycosidic linkage, and these are characterized by the stereochemical outcome of the degradation reaction. I f the stereochemistry of the linkage at the anomeric center is inverted in the product (cleaving to yield $\alpha$-glucose as a product), then it is an inverting enzyme. If, however, the stereochemistry of the linkage at the anomeric center is retained in the product (cleaving to yield $\beta$-glucose as a product), then the enzyme is retaining (185).

The basic principles of the mechanisms followed by these enzymes are well established $(53,94,154,185,186)$. I nverting enzymes use a single-displacement mechanism in which water attacks directly at the anomeric center, displacing the leaving group in a general acid/basecatalyzed process via a transition state with considerable oxocarbonium ion character (186). Retaining enzymes employ a double-displacement mechanism involving a covalent glycosyl-enzyme intermediate. The first step involves attack of an enzymatic nucleophile at the anomeric center with general acid-catalyzed displacement of the leaving group to yield a covalent glycosylenzyme acylal intermediate. In the second step, water attacks the anomeric center of this intermediate in a general base-catalyzed process to yield the product and to release the enzyme in its original protonation state $(94,154,186)$.

As mentioned previously, to try to elucidate the molecular mechanism of microbial breakdown of cellulose in naturally occurring lignocellulosics, researchers have utilized simpler model systems, such as "pure" cellulosic substrates and purified or cloned cellulase enzymes. However, ambiguities in the supramol ecular structures of natural cellulosic substrates and problems with enzyme purity make it difficult for us to fully understand the interactions that occur between the enzyme and the substrate at the molecular level $(5,6,15)$.

\section{Substrate Characteristics}

To better understand the enzymatic degradation of cellulose, it is important that the general chemical and physical features of the cellulose substrates are also accurately understood. Cellulose is usually found in close association with hemicellulose and lignin. In most cases cellul ose does not occur alone in a free threadl ike chain, as is found in the common substrates used in activity quantification, but is usually present in a bundle of fibrillar units with a supramolecular structure consisting of crystalline and amorphous regions (48, 142, 155). Typically, the crystalline region consists of several sheets of cellul ose chains arranged by both intra- and intermolecular hydrogen bonds. Cellulose species are known to exhibit different polymorphs, depending on the forms of cellulose I, II, III, IV, and X, which in some instances also contain subclassifications (38). Researchers continue to try to establish accurate supramol ecular structures of different cellulose species in native or modified forms. It is important to know which cellulase specificities are affected by even subtle differences in the stereochemical environment of the surfaces of different cellulose substrates $(185,186)$. Thus, the stereochemistry of cellulose chains may prove to be the raison d'être for both the existence of multiple isozymes of the individual monocomponents of cellulase enzymes and the synergistic

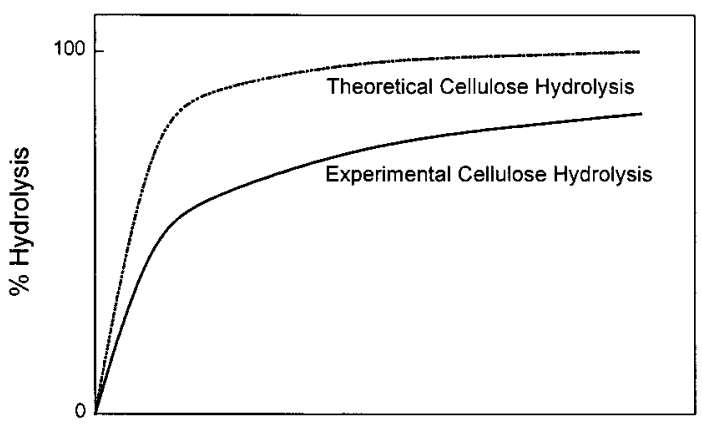

Reaction Time $\longrightarrow$

Figure 1. Typical time course for the enzymatic hydrolysis of lignocellulosic substrates.

effects exhibited by these monocomponents in the enzymatic saccharification of cellulosic substrates.

The actions of cellulase enzymes are also affected by the different molecular weights of cellulose substrates and numerous other physiochemical factors. The substraterelated factors that influence hydrolysis have not been easy to resolve (15). The role of the various substrate characteristics has been further compounded by the fact that the ultrastructure of cellulose has been a subject of much debate, with still no general agreement as to the arrangement of the microfibrils and their association with other components such as lignin and hemicellulose. As mentioned earlier, the bulk of the research to date has been with pure cellulosic substrates, where associations with other components have not been an issue. However, it is still not known with any degree of certainty what factors result in the slow hydrolysis rates of lignocellulosic substrates or what causes some substrates to be hydrol yzed faster than others. Accessibility probably plays a key role as lignocellulosic substrates that have been more extensively pretreated tend to be hydrolyzed faster (170). This is primarily due to the removal of extraneous substances such as lignin and hemicellulose. Although the exact role of lignin in limiting hydrolysis has been difficult to define. One of the most significant limitations is probably the effect of lignin on fiber swelling and its resulting influence on cellulose accessibility $(107,110)$

It is apparent that various characteristics within the lignocellulosic substrates can limit both the rate and degree of hydrolysis by cellulases. However, the action of cellulases also alters the inherent characteristics of lignocellul osic substrates as hydrolysis proceeds. Therefore, it is important to understand the contributions that both the substrate and the enzyme make to the total saccharification of the substrate.

Several substrate characteristics have been suggested to play key roles in determining both the rates and the degrees of hydrolysis. F or example, the initial rapid rate of hydrolysis followed by slower and sometimes incomplete hydrolysis (Figure 1) was proposed to be due to the rapid hydrolysis of the amorphous constituents of the cellulosic substrates. The recalcitrance of the residual material was thought to be due to a higher inherent degree of crystallinity. However, determining the limitations that the various substrate characteristics may present is severely handicapped by the limitations in the methods used to quantify these characteristics. For example, pore volume measurements are largely a function of the "probe" being employed and measurements of the degree of polymerization are restricted to substrates containing low levels of lignin, while the determination of crystallinity indices requires prior drying of the 
Table 1. Anatomical and Ultrastructural Characteristics of Cellulosic Fibers Modified by or Potentially Limiting Enzymatic Hydrolysis

\begin{tabular}{|c|c|c|c|}
\hline structural level & characteristic & description & reference \\
\hline $\begin{array}{l}\text { fibril } \\
\text { fiber }\end{array}$ & $\begin{array}{l}\text { molecular orientation } \\
\text { crystallinity }(\mathrm{Crl}) \\
\text { degree of polymerization } \\
\text { lattice structure } \\
\text { composition } \\
\text { particle size } \\
\text { intrinsic strength } \\
\text { dimensions } \\
\text { weight loss }\end{array}$ & $\begin{array}{l}\text { parrallel vs antiparrallel cellulose } \\
\text { ratio of crystalline to amorphous cellulose } \\
\text { molecular chain length of cellulose } \\
\text { Cellulose lattice (I, II, III, V or X) } \\
\text { structural moieties (carbohydrate \& lignin) } \\
\text { fibril dimensions } \\
\text { tensile strength } \\
\text { fiber length, cell wall thickness, coarseness } \\
\text { carbohydrate solubilization }\end{array}$ & $\begin{array}{l}(16,17,147) \\
(2,14,25,46,47,59,63,67-69,75,84, \\
\quad 100,109,130,132,148,153) \\
(46,51,58,69,78-8191,100,105,106, \\
\quad 109,129,144,159) \\
(7,63,69,70,93) \\
(59,60,96,107,109,131-133,161,187) \\
(4,14,50,107,109,130,153,200) \\
(23,71,73,100,104,124,162) \\
(23,63,73,104,131-133) \\
(13,18,21,22,26,27,30,36,39,43, \\
\quad 45-47,49,50,52,54,75,77,88,91, \\
\quad 92,107,112-116,121,129,151, \\
\quad 153,172,176,179,181,198,199) \\
(2,11,14,26,30,46,47,52,74,76,109, \\
\quad 111,130,156,161,170,171) \\
(11,123,125,126,161,162) \\
(11,52,59,60,100,167,182,187) \\
(10,17,18,32,41,57,63,72,89,101, \\
\quad 117,143,156,157,183)\end{array}$ \\
\hline
\end{tabular}

substrate, all of which likely limit the relevance of the derived values.

Although it is clear that the recalcitrance of some lignocellulosic substrates is greater than others during enzymatic saccharification and that this phenomenon may be related in part to the nature of the enzyme employed, it is likely that one or more of the structural and physiochemical features of the substrate affect the efficacy of hydrolysis. However, when contemplating these characteristics and identifying potential contributing factors or limitations, care must be taken to consider some undisputable principles (i) all samples of insoluble cellulose (both native and pretreated) are structurally nonuniform; (ii) the pretreatment method and conditions can effectively alter the structure of the original cellulose; (iii) native cellul ose contains inherent regions of highly ordered and disordered molecular polymers (i.e., crystalline and amor phous regions); (iv) considerable attention must be paid to the anatomical and structural "levels" of organization (i.e., microfibril, fibril or fiber) which is being modified and characterized during hydrolysis (Table 1). Although this latter point identifies anatomical feactures that are closely inter-related, researchers often ignore the gross differences and limitations that macrostrutural characteristics (fiber) can have on the microstructural (elementary microfibril) structure.

\section{Substrate Factors Limiting Hydrolysis}

Degree of Polymerization. A vast array of studies have focused on the enzymatic attack of cellulose by primarily examining the release of reducing sugars from insoluble modified cellulose or water-soluble cellulose derivatives. However, only a limited number have examined the effects of enzymatic saccharification on the micromolecular structure of insoluble cellulose substrates. The degradation of insoluble cellul osic substrates eventually results in the generation of soluble, more easily quantifiable cello-oligosaccharides (cellulosic molecules with a degree of polymerization of $<6$ units) and penultimately to the generation of cellobiose and glucose. However, particularly with the saccharification of naturally occurring lignocellulosics, there is a tendency for a substantial amount of the residual cellulosic material to remain in a recal citrant, insoluble state after hydrolysis is stalled. A number of researchers have used relatively homogeneous cellulosic substrates to show that the molecular weight or degree of polymerization (DP, num- ber of glucosyl residues per cellulose chain) of the residual material following hydrolysis is very similar, or only marginally reduced, when compared to that of the original sample $(119,125,136,178)$. These results seemed to indicate that the cellulosic components of any particular molecular weight are left intact following extensive hydrolysis reactions. In contrast, other workers have shown that the DP of wood-derived cellulose fragments decreased with increasing reaction times. However, these substrates were prepared using chemical treatments which may have altered the natural molecular structure of the inherent substrate $(130,132)$. While the latter reports showed a substantial reduction in DP with hydrolysis, it was evident that the residual cellulose substrate molecules were relatively intact and still retained significant molecular weights. In related work, Puls and Wood (129) demonstrated a general reduction in the DP of wood $\alpha$-cellulose that had been subject to 7 days of hydrolysis, achieving approximately $60 \%$ saccharification of the samples. However, these authors indicate that the mechanism of cellulose degradation (i.e., DP reduction) was not consistent among organisms of different classification, suggesting that, although cellulose ultrastructure contributes to limited hydrolysis, so does the nature of the cellulase complex (129).

The early observations of Puls and Wood (129) have been further elaborated by other authors who have demonstrated that the in vivo mechanism of cellulose degradation differs fundamentally among wood-degrading fungi and, consequently, results in different modes of decay (78). These and other authors $(79,159)$ have also shown that recombinant cellulase monocompents (both endoglucanases and cellobiohydrolases) effectively reduce the DP of different purified cellulose substrates by various mechanisms $(79,159)$, suggesting that depolymerization was largely a function of the nature of the cellulosic substrate being attacked. However, regardless of the substrate being solubilized, there seems to be a "leveling off" of the cellulose DP being attacked. This is claimed to be due to the increased recalcitrance of the residual (crystalline) cellulose (9). Other researchers have shown that endoglucanase I and cellobiohydrolase II of Trichoderma reese act synergistically to solubilize native cellul ose but not to decrease its molecular size distribution (81). These findings support the hypothesis that the cooperative efforts between individual cellulase monocompents (EGs 
and $\mathrm{CBHs}$ ) may alter the nature of the substrate by employing yet another synergistic mechanism.

These data indicate that the innate cellulose ultrastructure that affects the degree or extent of enzymatic degradation is the inherent degree of polymerization (DP). Beyond a definite molecular weight range, cellulose is recal citrant to hydrolysis, and degradation is limited (15). However, it remains unclear as to whether cellulose DP is a contributing limiting factor, or whether this structural characteristic is associated with other factors such as crystallinity, accessibility or available surface area, which ultimately result in slower rates and limited degrees of hydrolysis.

Crystallinity. Crystallinity, while originally thought to play a major role in limiting hydrolysis $(46,47)$, now seems to be less critical. Several workers have shown that, when all other substrate factors are similar, the degree of crystallinity of the substrate has no effect on hydrolysis (130). In some of the studies where crystallinity was suggested to be important, the substrates used were mechanically pretreated lignocellulosic materials where any decrease in crystallinity was invariably accompanied by a decrease in other substrate characteristics such as particle size and an increase in available surface area (130). The observed alterations in the rate and extent of saccharification are likely governed by the associated factors rather than crystallinity itself.

One of the earliest studies focusing on substrate characteristics affecting hydrolysis looked at the changing degree of crystallinity of pure cellulose substrates by measuring the moisture regain values (178). This work suggested that the decreased hydrolysis proceeded due to the preferential removal of the amorphous cellulose component. This was the first evidence to suggest that the amorphous component of cellulose was hydrolyzed first, leaving the more recal citrant crystalline component unhydrolyzed. While several subsequent studies offered some evidence to support this theory $(46,47,55,136,148$, 153), others have refuted the existence of any correlation between the degree of crystallinity of a substrate and its susceptibility to hydrolysis $(31,130,132,170)$. Those studies that found a positive correlation between crystallinity and hydrolysis rate used relatively pure cellulosic substrates, which had been mechanically treated, and likely changed their crystallinity indices. In addition, it has been suggested that the treatments that caused a decrease in crystallinity also resulted in an increase in specific surface area which may have been the cause of any increase in hydrolysis rate $(25,26)$. Consequently, it is difficult to separate these two physical properties of cellul ose, and more recent studies have included both of these factors in empirical equations relating the structural features of cellulose to the rates of hydrolysis (47, 54). While these "ideal" substrates have been invaluable in clarifying the mechanism of individual enzyme activities, they probably do not fully reflect the actual action of cellulase enzymes on natural heterogeneous lignocelIulose substrates.

When natural lignocellulosics substrates have been used to assess the effect that crystallinity has on impeding the hydrolysis reaction, most studies have failed to demonstrate a positive correl ation between crystal linity and rates of hydrolysis $(132,165,166)$. In fact, these studies have shown that the steam pretreatment of lignocellul osic substrates increases the crystall inity index of the substrate at the same time as it enhances the ease of hydrolysis of the substrate. This contradicts the theory that crystalline cellulose is hydrolyzed more slowly than amorphous cellulose. It is apparent that, with these

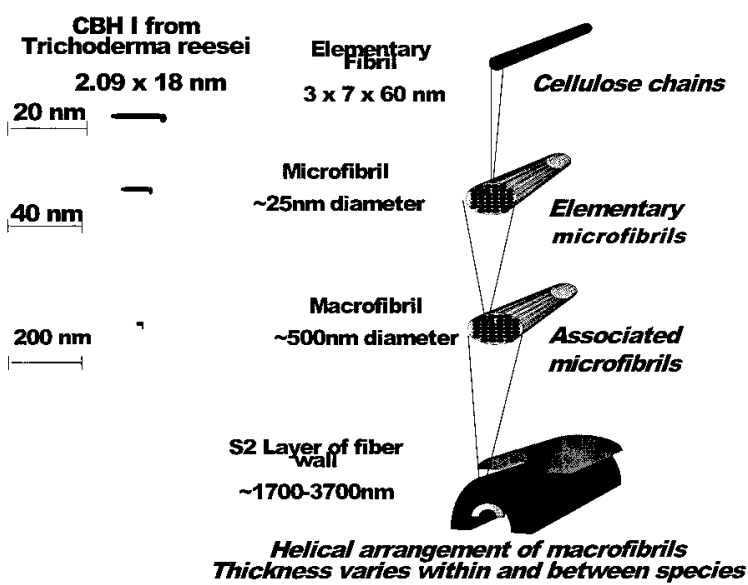

Figure 2. Relative size of wood cell wall components and cellobiohydrolase I (CBH I) from Trichoderma reesei.

substrates, the factors which are influencing the accessibility of cellulose do not include crystallinity. However, it is also known that the hydrolysis of crystalline cellulose seems to have more stringent prerequisites than the hydrolysis of amorphous cellulose because not all cellulase systems are capable of hydrolyzing crystalline substrates. Cellulase complexes that are capable of hydrolyzing both forms of cellulose are characterized by having at least one tightly binding cellobiohydrolase (82). Synergism seems to be particularly important for crystalline cellulose hydrolysis. It has been shown that the presence of a cellobiohydrolase is important in the hydrolysis of crystalline cellulose, only if it is capable of exhibiting synergism with the other cellulase components (90). Amorphous cellulose can be hydrolyzed by both endoglucanases and cellobiohydrolases, while crystalline cellulose is largely hydrolyzed by cellobiohydrolases. Thus, crystallinity probably influences hydrolysis when synergism is lacking due to an incomplete cellulase system or an insufficient enzyme loading, both of which are enzyme-related factors.

In a natural environment, cellulases are accompanied by a barrage of other activities produced by the microorganism such as hemicell ulases and ligninases that aid the hydrolysis of cellul ose by degrading the hemicellulose and lignin associated with it. In order for cellulases to hydrolyze cellulosic substrates, they first must be able to access the fibrils which are encased along with hemicellulose and lignin into microfibrils. For example, it can easily be seen how cellobiohydrolase I (CBH I) from Trichoderma reese is capable of accessing the cellulose within elementary microfibrils (Figure 2) and how factors, such as crystallinity, could influence hydrolysis at this level. However, when these elementary microfibrils are associated into fibrils and further into the fiber walls, the extent to which $\mathrm{CBH}$ I can access the cellulose chains is reduced dramatically and factors such as accessible surface area and lignin content must be more influential than characteristics such as crystallinity or the degree of polymerization of the cellul ose. This is directly related to the enzyme's ability to only access the surface layers of microfibrils and, furthermore, only those fibrils not encased or surrounded by lignin. Thus, cellul ose accessibility and available surface area may be more influential than crystallinity in determining the rate and extent of hydrolysis.

Accessible Surface Area. Various methods have been used to measure accessible surface area, including the BET (Bennet-Emmit-Teller) method, which measures the surface area available to a nitrogen molecule (46). 
As this technique involves drying the substrate, it obviously does not give a measurement that is comparable to the substrate in its swollen state. Another problem with this technique is the difference in size between the nitrogen molecule and that of an enzyme. Since the nitrogen molecule is smaller, it has access to pores and cavities on the fiber surface that the cellulase enzyme cannot enter. Not surprisingly, researchers that have used this technique have devel oped little evidence to support the theory that surface area plays a role in hydrolysis.

A more suitable technique for lignocellul osic substrates measurement is the solute exclusion technique, which determines the area available in the form of pores and cavities in the fiber wall (59, 111, 161), which are accessible to dextran molecules of various sizes. This method measures the cell wall capillaries, such as spaces between microfibrils, rather than gross capillaries, such as the cell lumen, pit apertures, and pit membranes. The pore volume technique can be carried out on never-dried substrates, and consequently it is more representative of the actual surface area accessible to the enzyme molecule in solution. However, for the pore volume to be correlated to accessible surface area, the pore geometry has to be assumed. Stone and Scallan (160), who originally developed this technique for lignocellulosic substrates, assumed that the pores consisted of spaces between lamellae or layers of lignocellulosic material. The pore volume technique has been used numerous times to correlate the surface area available in the form of pores to the different accessibilities of various substrates. The first such published correlation found that the relative digestibility of a series of cellulosic substrates was directly proportional to the accessibility of a molecule of 30-40 $\AA$ in diameter (161). It was suggested that this was evidence of the size of the enzyme. This was a good estimation, in retrospect, since $\mathrm{CBH}$ I from Trichoderma reesei has subsequently been shown to be a tadpoleshaped protein, with a total length of $180 \AA$, while the catalytic core has dimensions of $50 \times 60 \times 40 \AA$ (34, 35, 42). Others have found similar correlations between pore vol ume and hydrolyzability of lignocellulosic substrates, including a study in which a linear relationship was shown between the initial hydrolyzability of a substrate and its accessibility to a molecule of nominal diameter $51 \AA$ (60).

Other investigators have shown that the removal of hemi cellulose and the redistribution of lignin during the pretreatment of Pinus radiata increases the surface area present in the form of pores, thus increasing the accessibility to enzymes (187). This study also indicated the significant difference between hardwood and softwood substrates in terms of their pore volume and ease of hydrolysis. It was shown that the pore volume of white pine was only half of the value obtained with a mixed hardwood substrate and that it was subsequently hydrolyzed less efficiently (60). The hemicellulose and lignin appear to occupy smaller spaces in softwoods such that their removal and/or redistribution results in a smaller pore volume than would occur for hardwoods.

Particle Size/Specific Surface Area. Another parameter which has been studied with regard to its influence on enzymatic hydrolysis is the average particle size of the cellulosic substrates. Since adsorption is a prerequisite step in the hydrolytic process, it seems intuitive that specific surface area would have an effect on hydrolysis rates since a higher surface area-to-weight ratio should mean more available adsorption sites per mass of substrate. However, with cellulosic substrates such as cotton linters and mi corocrystalline cellulose, there has been very little evidence reported to support this theory, with several studies indicating no correlation between average particle size and hydrolysis rates (141, $151,153)$. However, these studies measured average particle sizes, and the overall differences in specific surface area may not have been of sufficient significance to highlight any influence on rates. A further issue which has not yet been fully resolved by these studies is the extent to which the differences in average particle size influenced enzyme adsorption.

In contrast to the dearth of evidence found to support a correlation between particle size and hydrolysis rates of relatively pure cellulosic substrates, there is some evidence to support such a link with lignocellulosic substrates. For example, it has been shown that the smaller sized fractions within pulps are hydrolyzed preferentially in the initial stages of the hydrolysis reaction $(71,104)$. Lignocellulosic substrates are heterogeneous in their particle size composition, and it has been shown that, within the fiber population of a lignocelluIosic substrate, the fines have a significantly higher pore volume than do the larger fibers (87). With steampretreated substrates, it has been shown that, when the severity of the pretreatment is increased, the average particle size is decreased and the hydrolysis yields are increased $(149,150,165)$. However, most of this work showed only an indirect correlati on since it has not been proven that the increased specific surface area resulted in higher hydrolysis yields. As a result, there is, as yet, no evidence to support the theory that increased specific surface area leads to increased adsorption since none of the previously mentioned authors have measured this parameter. The higher recalcitrance of softwoods could be due in part to the larger fiber size of these substrates. This would make them less susceptible to the beneficial particle size reduction caused by steam pretreatment.

Lignin Distribution. The removal of lignin and hemicellul ose invariably causes extensive changes in the structure and accessibility of cellulose. Their removal leaves the cellulose more accessible and more open to swelling on contact with cellulases $(60,161)$. Since lignocellulosic materials serve a structural purpose, they are, by nature, relatively resistant to microbial attack. Thus, the enzymatic hydrolysis of lignocellulosic materials is low prior to lignin removal. Lignin is thought to influence cellulase accessibility to cellulose in more ways than by just acting as a barrier to prevent the enzymes from effectively binding to the cellulose (177). For example, it has been shown that lignin removal increases the porosity of both kraft and sulfite pulps and that the increase in median pore width corresponded to the average molecular weight of the lignin molecules removed $(1,160,161,168)$. It has also been shown that the increase in pore volume observed after lignin removal corresponds to the substrate's increased susceptibility to hydrolysis $(59,187)$. An issue which further complicates the picture is the differences observed in the response of hardwood and softwood substrates to chemical treatments designed to redistribute and/or remove lignin. It has been shown by several authors that softwood substrates are inherently more resistant to lignin removal and redistribution and, consequently, to enzymatic hydrolysis $(60,131,161)$. In a recent study in which seven substrates of different origin were studied, it was conclusively shown that softwoods were most recalcitrant to lignin removal and enzymatic hydrolysis (96).

Lignin is also thought to negatively influence the hydrolysis reaction by irreversibly adsorbing the cellulase enzymes, thus preventing their action on cellulose. This 
has been observed numerous times in the literature, especially in relation to steam-exploded substrates (24, 26,88 ). In a study in which various lignaceous residues were studied, it was apparent that the extent to which lignin adsorbs enzymes depends very much on the nature of the lignin itself (163). It has been shown that lignin adsorption of enzyme is decreased as the severity of pretreatment increases (120-122). Thus, it appears that, while the predominant effect of lignin removal is the creation of additional surface area, it may also increase the levels of enzyme adsorption to cellulose. Therefore, the lignin itself may exert a rate-limiting effect on cellulose hydrolysis by nonhydrophobically binding the cellulase enzymes.

\section{Enzyme Factors Influencing Cellulose Hydrolysis}

Several factors associated with the nature of the cellulase enzyme system have been suggested to be influential in the hydrolysis process. These include endproduct inhibition of the cellulase complex, thermal inactivation, and irreversible adsorption of the enzymes $(24,37,86,145)$. The problems of end-product inhibition have been largely dealt with through the addition of $\beta$-glucosidase, which hydrolyzes cellobiose to glucose, thereby preventing inhibition of cellobiohydrolases by cellobiose (12). While thermal inactivation and irreversible adsorption undoubtedly play some role in the hydrolysis reaction, the most significant enzyme-related factors that offer the most influence on hydrolysis are synergism and adsorption.

Synergism. Synergism, which was first described over 30 years ago (98), occurs when the combined action of two or more enzymes leads to a higher rate of action than the sum of their individual actions. It is widely accepted that the cellulases of Trichoderma reese cooperate such that EG I and II act randomly al ong the cellulose chains and thus produce sites for $\mathrm{CBH} \mathrm{I}$ and II to act as exoenzymes, releasing cellobiose as the main product. A third enzyme, $\beta$-glucosidase, though not strictly a cellulase, is necessary to hydrolyze cellobiose, thereby preventing end-product inhibition of cellobiohydrolases. The individual components of Trichoderma reesei cellulase system have been largely classified according to their activities on substrates such as Avicel and carboxymethylcellulose (CMC). Although this classification holds true to a large extent, the difference between $\mathrm{CBH}$ s and $\mathrm{E}$ Gs is not always so clear-cut. For example, the cellobiohydrolases of Trichoderma reesei have been shown to have limited endoglucanase activity and Trichoderma reese endoglucanases have exhibited relatively high activities on Avicel under certain conditions $(114,115,158)$. I ssues such as these have created doubts about this simplified picture of synergism. Beyond just Trichoderma reese, not all combinations of cellobiohydrolases and endoglucanases exhibit synergism. What is it that differentiates one $\mathrm{CBH}$ from another?

An observation which highlights the complexity of synergism is the interactions observed between cellobiohydrolases defined as exo-exo synergism (44). There have been many explanations suggested for this phenomenon including, one based on the fact that $\mathrm{CBH} \mathrm{I}$ and II act preferentially from opposite ends of the cellulose chain, cleaving the reducing and nonreducing ends, respectively, making it possible that they are creating new adsorption sites for each other. It has also been suggested that the synergism between the cellobiohydrolases of Trichoderma reese is due to the fact that $\mathrm{CBH}$ I binds more tightly than $\mathrm{CBH}$ II. This allows $\mathrm{CBH}$ I to disperse crystalline cellulose through mechanochemical effects, thus creating new sites for CBH II (82). More significant in terms of rates of hydrolysis of cellulosic substrates with mixed cellulase preparations is the observation that the degree of synergism observed with many mixtures of cellulases has been shown to be substrate-dependent since the enzymes may exhibit synergism on some substrates and not on others. It was shown that, with the major Trichoderma reese cellulases, synergism was maximum with the more crystalline substrates (113). However, it has also been observed that synergism between $\mathrm{CBH}$ I and EG I was highest when assayed against semicrystalline substrates and almost zero when using a fully crystalline substrate such as Valonia cellulose (66). A recent observation with Clostridium stercocarium cellulases raises more questions about the link between substrate quality and synergism. This study found that, with a range of Avicel substrates of different particle sizes, synergism was highest with the largest particle size and lowest with the smallest particle size (138). It has been suggested that the gradual loss of synergism was one of the key factors that limited hydrolysis efficiency of microcrystalline cellulose (164). Researchers have al so observed a gradual decrease in the specific activity of the adsorbed enzyme during the hydrolysis of Avicel (121). With so much evidence pointing toward a link between cellulose structural characteristics and synergism when using ideal substrates, it naturally raises the question as to what role synergism plays in the hydrolysis of more structurally heterogeneous lignocellulosic substrates. However, very little, if any, work has examined the role of synergism in the hydrolysis of such substrates.

Adsorption. The hydrolysis of cellulose is distinct from most enzymatic reactions in that the substrate is insoluble and requires the adsorption of the enzyme prior to hydrolysis. Since the efficient hydrolysis of lignocelIul osic substrates requires effective interaction between the substrate and enzyme, the adsorption reaction has been extensively studied. It has been shown that cellulase adsorption is facilitated by a cellulose-binding domain (CBD) in addition to a catalytic domain. This modular structure is shared by other polysaccharide-degrading enzymes (184), and to date, more than one hundred and twenty CBDs have been classified into 10 families on the basis of their amino acid sequences (176). The catalytic domain and the cellulose-binding domain are joined by a linker region which is susceptible to proteolytic cleavage, thus facilitating their separation and characterization. The role of CBDs in hydrolysis has not been precisely ascribed due to our current limited understanding of the binding reaction. van der Waals contacts and hydrogen bonds are known to be dominant forces in carbohydrate-binding proteins. The CBDs generally have a low content of charged amino acids and a high content of hydroxy amino acids. Aromatic amino acid residues, tryptophan and tyrosine, are thought to pack onto the sugar rings, conferring additional specificity and stability to the enzyme-substrate complexes (95). The importance of aromatic amino acid residues for adsorption has been demonstrated by site-directed mutagenesis (139, 140). The CBD of cellobiohydrolase I interacts with cellulose through three conserved tyrosine residues on the more hydrophillic side of a wedge-shaped molecule.

Two explanations have been put forward to explain the need for and the interaction of CBDs with cellulose. The most obvious explanation is that the CBD serves to increase the local concentration of enzyme at the cellulose surface. The other theory proposes that the CBD is instrumental in liberating cellulose chains from the 
surface of crystalline cellulose through a nonhydrolytic mechanism $(33,169)$. It has been shown that, in some cases, the removal of the CBD reduces the hydrolytic efficiency of the enzymes on crystalline cellulose but not on amorphous cellulose (175). It has also been shown that the addition of a CBD to an enzyme which does not al ready have one results in an increase in its activity, as well as its synergistic interaction with other enzymes (97).

It should be noted that most studies have focused on the analysis of binding of purified enzymes to relatively pure insoluble cellul oses. While these studies have cast considerable light on the mechanism of binding and substrate specificity of the individual cellulases, they do not tell us much about how the enzymes behave in mixtures or how their adsorption profile changes with more lignified substrates. The reactions of cellulases with cellulose are complex and are affected by the physiochemical properties of the substrate such as crystallinity, degree of polymerization, lignin content, and surface area $(25,91,92,120,121)$. The binding of cellul olytic enzymes is complex due to substrate heterogeneity with areas of differing crystallinity and chemical composition. Even within a perfect crystal, the crystal has inequivalent faces and corners resulting in differing adsorption specificities of individual cellulase components $(17,18)$. It has been shown with both an exocellulase and an endocellulase from Irpex lacteus that adsorption is more thermodynamically favorable with more crystalline substrates, suggesting that these cellulases preferentially adsorb to crystalline cellul ose $(68,69)$. Some observations indicate that lignin can have a significant effect on cellulase adsorption, in that it has been shown to irreversibly adsorb cellulases $(120-122,163)$. The tightness of adsorption has also been suggested to be one of the most important factors determining the effectiveness of a cellulase, particularly with respect to synergism $(82,83)$. It has been shown that the removal of the CBD decreases individual enzyme activity on crystalline substrates but not on amorphous ones. Thus, it would seem that adsorption is not as important for amorphous substrates which are more easily hydrolyzed, while crystalline substrates require the concerted action of more than one enzyme.

\section{Conclusion}

While the heterogeneity of lignocellulosic substrates and the multiplicity of the enzymes capable of hydrolyzing it do not make the process an easy one to understand, much has been learned about the hydrolysis reaction and the factors which control it. For example, it is known that increasing the surface area of lignocellulosic substrates increases their hydrolysis rates and that lignin removal also greatly increases the rate and yield of hydrolysis. However, the situation is further complicated by the number of different sources of lignocellul osic substrates. While there have been some generalities observed when looking at the response of various agricultural and woodderived substrates to pretreatment methods, such as the effect of increasing surface area and decreasing lignin content, the relative response of the different substrates to pretreatment has varied widely. In all of this work, it is apparent that the efficacy of the cellulase enzyme in hydrolyzing these substrates is inextricably linked to the structural characteristics of the substrate. As mentioned earlier, the adsorption reaction, which is one of the most important steps in the hydrolysis of insoluble lignocelIulosic substrates, is significantly influenced by lignin distribution. Therefore, its characteristic dramatically affects cellulose accessi bility and available surface area.
Although the effect of particle size is expected to significantly affect the rate and completeness of hydrolysis, it remains to be proven conclusively that, as the particle size decreases, the total available surface area per gram of substrate increases and, consequently, so does the efficiency of hydrolysis.

It has been shown that the synergistic interaction of different cellulases can be of significant benefit in increasing the hydrolysis rates of complex substrates. However, it is apparent that the extent to which cellulases exhibit synergism is substrate-dependent, with some mixtures showing optimum synergism on crystalline substrates while others do so with semicrystalline substrates. As a result, it is difficult to draw conclusions as to the role that synergism may play in the hydrolysis of lignocellul osic substrate since there has been very little research done on this aspect of the hydrolysis reaction.

Thus, there is still much to be learned about the mechanism of hydrolysis of lignocellul osic substrates as opposed to the "purer" model cellulosic substrates used to date. It is clear that future work should be directed at determining the effect of gross physical characteristics such as fiber size, lignin distribution, cell wall thickness, etc. on hydrolysis. It is possible that much of what we have learned by using ideal substrates, such as the influence of cellulose crystallinity on synergism and adsorption, is clouded by the influence of factors such as fiber size, cell wall thickness, accessible surface area, and the extent of fibrillation. These factors will very likely affect the hydrolysis of "real" substrates, such as those derived from agricultural and forestry sources.

\section{References and Notes}

(1) Ahlgren, P. A.; Yean, W. Q.; Goring, D. A. I. Chlorite delignification of spruce wood. Comparison of the molecular weight of the lignin dissolved with the size of the pores in the cell wall. Tappi 1971, 54, 737-740.

(2) Akishima, Y.; Isogai, A.; Kuga, S.; Onabe, F.; Usada, M. Kinetic studies on enzymatic hydrolysis of celluloses for evaluation of amor phous structures. Carbohydr. Polym. 1992, 19, 11-15.

(3) Ander, P. The cellobiose-oxidizing enzymes CBQ and CbO as related to lignin and cellulose degradation - a review. FEMS Microbiol. Rev. 1994, 13, 297-312.

(4) Armand, S.; Drouillard, S.; Schulein, M.; Henrissat, B.; Driguez, H. A bifunctionalized fluorogenic tetrasaccharide as a substrate to study cellulases. J . Biol. Chem. 1997, 272, 2709-2713.

(5) Atalla, R. H. The structures of cellulose. Mater. Res. Soc. Symp. Proc. 1990, 197, 89-98.

(6) Atalla, R. H. The Structures of Native Cel luloses. In Foundation for Biotechnical and Industrial Fermentation Research; Atalla, R. H., Ed.; Espoo: Finland, 1993; Vol. 8, pp 25-39.

(7) Atalla, R. H.; Ellis, J. D.; Schroeder, L. R. Some effects of elevated temperatures on the structure of cellulose and its transformation. J. Wood Chem. Technol. 1984, 4, 465-482.

(8) Bao, W.; Renganathan, V. Cellobiose oxidase of Phanerochaete chrysosporium enhances crystalline cellulose degradation by cellulases. FEBS Lett. 1992, 302, 77-80.

(9) Battista, O. A. Hydrolysis and crystallization of cellulose. Ind. Eng. Chem. 1950, 42, 502-507.

(10) Behera, B. K.; Arora, M.; Sharma, D. K. Scanning electron microscopic (SEM) studies on structural architecture of lignocellulosic materials of Calotropis procera during its processing for saccharification. Bioresour. Technol. 1996, 58, 241-245.

(11) Bendzalova, M.; Pekarovicova, A.; Kokta, B. V.; Chen, R. B. Accessibility of swollen cellulosic fibres. Cellul. Chem. Technol. 1996, 30, 19-32.

(12) Breuil, C.; Chan, M.; Gilbert, M.; Saddler, J . N. Influence of $\beta$-glucosidase on the filter paper activity and hydrolysis of lignocellul osic substrates. Bioresour. Technol. 1992, 39, 139142. 
(13) Castellanos, O. F.; Sinitsyn, A. P.; Vlasenko, E. Y. Comparative evaluation of hydrolytic efficiency toward microcrystalline cellul ose of Penicillium and Trichoderma cellulases. Bioresour. Technol. 1995, 52, 119-124.

(14) Caulfield, D. F.; Moore, W. E. Effect of varying crystallinity of cellulose on enzymic hydrolysis. Wood Sci. 1974, 6, 375379.

(15) Chang, M. M.; Chou, T. Y. C.; Tsao, G. T. Sturcture, pretreatment and hydrolysis of cellulose. In Advances in Biochemical Engineering Bioenergy; Fieshter, A., Ed.; SpringerVerlag: Berlin, Germany, 1981; Vol. 20, pp 15-42.

(16) Chanzy, H.; Dube, M.; Marchessault, R. H. Shish-kebab morphol ogy-oriented recrystallization of mannan on cellulose. Tappi 1978, 61, 81-82.

(17) Chanzy, H.; Henrissat, B. Undirectional degradation of Valonia cellulose microcrystals subjected to cellulase action. FEBS 1985, 184, 285-288.

(18) Chanzy, H.; Henrissat, B.; Vuong, R.; Schülein, M. The action of 1,4- $\beta$-D-glucan cellobiohydrolase on Val onia cellulose microcrystals. FEBS Lett. 1983, 153, 113-118.

(19) Claeyssens, M.; Aerts, G. Characterisation of cellulolytic activities in commercial Trichoderma reese preparations: An approach using small, chromogenic substrates. Bioresour. Technol. 1992, 39, 143-146.

(20) Claeyssens, M.; Tomme, P.; Brewer, C. F.; Hehre, E. J . Stereochemical course of hydrolysis and hydration reactions catalysed by cellobiohydrolase I and II from Trichoderma reesei. FEBS 1990, 263, 89-92.

(21) Claeyssens, M.; van Tilbeurgh, H.; Kamerling, J . P.; Berg, J .; Vrsanska, M.; Biely, P. Studies of the cellulolytic system of the filamentous fungus Trichoderma reese QM 9414. Substrate specificity and transfer activity of endoglucanase I. Biochem. J . 1990, 270, 251-256.

(22) Claeyssens, M.; Van Tilbeurgh, H.; Tomme, P.; Wood, T.; McRae, S. I. Fungal cellulase systems. Comparison of the specificities of the cellobiohydrol ases isolated form Penicillium pinophilum and Trichoderma reesei. Biochem. J . 1989, 261, 819-825.

(23) Clark, T. A.; Allison, R. W.; Kibblewhite, R. P. Effects of enzymatic modification on radiata pine kraft fibre wall chemistry and physical properties. Appita 1997, 50, 329-335.

(24) Cleresci, L. S.; Sinitsyn, A. P.; Saunders, A. M.; Bungay, $H$. R. Recycle of cellulase enzyme complex after hydrolysis of steam-exploded wood. Appl. Biochem. Bi otechnol. 1985, 11, 433-443.

(25) Converse, A. O. Substrate factors limiting enzymatic hydrolysis. In Conversion of Forest and Agricultural Plant Residues; Saddler, J . N., Ed.; C. A. B. International: Wallingford, U.K., 1993; pp 93-106.

(26) Converse, A. O.; Ooshima, H.; Burns, D. S. Kinetics of enzymatic hydrolysis of lignocellulosic materials based on surface area of cellulose accessible to enzyme and enzyme adsorption on lignin and cellulose. Appl. Biochem. Biotechnol. 1990, 24/ 25, 67-73.

(27) Coughlan, M. P. Cellulose hydrolysis: the potential, the problems and relevant research at Galway. In Cellulases: Production, Properties and Applications; Coughlan, M. P., Ed.; Galway, 1985; Vol. 13, pp 405-416.

(28) Coughlan, M. P. Enzymatic hydrolysis of cellulose: An overview. Bioresour. Technol. 1992, 39, 107-115.

(29) Coughlan, M. P. Mechanisms of cellulose degradation by fungi and bacteria. Anim. Feed Sci. Technol. 1991, 32, 77100.

(30) Coughlan, M. P. The properties of fungal and bacterial cellulases with comment on their production and application. Biotechnol. Genet. Engin. Rev. 1985, 3, 39-109.

(31) Cowling, E. B.; Brown, W. Sturtural features of cellulosic materials in relation to enzymatic hydrolysis. In Cellulases and Their Applications; Hajny, G. J ., Reese, E. T., Eds.; Advance Chemical Series, 1969; Vol. 95, pp 152-187.

(32) Daniel, G. Use of electron microscopy for aiding our understanding of wood biodegradation. FEMS Microbiol. Rev. 1994, 13, 199-233.

(33) Din, N.; Gilkes, N. R.; Tekant, B.; Miller R. C., J r.; Warren, R. A. J .; Kilburn, D. G. Nonhydrolytic disruption of cellulose fibres by the binding domain of a bacterial cellulase. Bio/ Technol ogy 1991, 9, 1096-1099.

(34) Divne, C.; Sinning, I.; Ståhl berg, J .; Pettersson, G.; Bailey, M.; Siika-aho, M.; Margolles-Clark, E.; Teeri, T.; J ones, T. A. Crystallization and preliminary $X$-ray studies on the core proteins of Cellobiohydrolase I and Endoglucanase I from Trichoderma reesei. J . Biol. Chem. 1993, 234, 905-907.

(35) Divne, C.; Ståhlberg, J .; Reinikainen, T.; Ruohonen, L.; Pettersson, G.; Knowles, J. K. C.; Teeri, T. T.; J ones, T. A. The three-dimensional crystal structure of the catalytic core of Cellobiohydrolase I from Trichoderma reesei. Science 1994, 265, 524-528.

(36) Donaldson, L. A. Ultrastructure of wood cellulose substrates during enzymatic hydrolysis. Wood Sci. Technol. 1988, 22, 33-41.

(37) Eklund, R.; Galbe, M.; Zacchi, G. Optimisation of temperature and enzyme concentration in the enzymatic saccharification of steam pretreated willow. Enzyme Microb. Technol. 1990, 12, 225-228.

(38) Ellefsen, O.; Tonnesen, B. A. In Cellulose and Cellulose Derivatives IV; Bikales, Segal, Eds.; J ohn Wiley: New York, 1971.

(39) Enari, T.-M.; Niku-Paavola, M.-L. Enzymatic hydrolysis of cellulose: Is the current theory of the mechanisms of hydrolysis valid? CRC Crit. Rev. Biotechnol. 1987, 5, 67-87.

(40) Eriksson, K.-E.; Wood, T. M. Biodegradation of cellulose. In Biosynthesis and Biodegradation of Wood Components; Higuchi, T., Ed.; Academic Press: New York, 1985; pp 469503.

(41) Eriksson, K.-E. L. Fungal degradation of wood components. Pure Appl. Chem. 1981, 53, 33-43.

(42) Esterbauer, H.; Hayn, M.; Abuja, P. M.; Claeyssens, M. Structure of cellulolytic enzymes. In Enzymes in Biomass Conversion; Leatham, G. F., Himmel, M. E., Eds.; American Chemical Society: Washington, D.C., 1991; Vol. 460, pp 301312.

(43) Esterbauer, H.; Steiner, W.; Kreiner, W.; Sattler, W.; Hayn, M. Comparison of enzymatic hydrolysis in a worldwide round robin assay. Bioresour. Technol. 1992, 39, 117-123.

(44) Fägerstam, L. G.; Pettersson, L. G. The 1,4- $\beta$-glucan cellobiohydrolases of Trichoderma reese QM9414. FEBS Lett. 1980, 119, 97-100.

(45) Fan, L. T.; Gharpuray, M. M.; Lee, Y.-H. Cellulose Hydrolysis; Springer-Verlag: Berlin, Germany, 1987.

(46) Fan, L. T.; Lee, Y.-H.; Beardmore, D. H. Mechanism of the enzymatic hydrolysis of cellulose: Effects of major structural features of cellulose on enzymatic hydrolysis. Biotechnol. Bioeng. 1980, 22, 177-199.

(47) Fan, L. T.; Lee, Y.-H.; Beardmore, D. R. The influence of major structural features of cellulose on rate of enzymatic hydrolysis. Biotechnol. Bioeng. 1981, 23, 419-424.

(48) Fengel, D.; Wegener, G. Wood: Chemistry- Ultrastructure - Reactions; Walter de Gruyter: Berlin, Germany, 1983.

(49) Fujii, M.; Mori, J .; Homma, T.; Taniguchi, M. Synergy between an endoglucanase and cellobiohydrolases from Trichoderma koningii. Chem. Eng. J . Bi ochem. Eng. J . 1995, 59, 315-319.

(50) Gama, F. M.; Carvalho, M. G.; Figueiredo, M. M.; Mota, $M$. Comparative study of cellulose fragmentation by enzymes and ultrasound. Enzyme Microb. Technol. 1997, 20, 12-17.

(51) Gama, F. M.; Faro, C. J .; Teixeira, J . A.; Mota, M. New methodology for the characterization of endoglucanase activity and its application on the Trichoderma longibrachiatum cellulolytic complex. Enzyme Microb. Technol. 1993, 15, 5761.

(52) Gama, F. M.; Mota, M.; Teixeira, J . A. Cellulose morphology and enzymatic reactivity: A modified solute exclusion technique. Biotechnol. Bioeng. 1994, 43, 381-387.

(53) Gebler, J.; Gilkes, N. R.; Claeyssens, M.; Wilson, D. B.; Béguin, P.; Wakarchuk, W. W.; Kilburn, D. G.; Miller, R. C., J r.; Warren, R. A. J .; Withers, S. G. Stereoselective hydrolysis catalyzed by related $\beta$-1,4-Glucanases and $\beta$-1,4-Xylanases. J . Biol. Chem. 1992, 267, 12559-12561.

(54) Gharpuray, M. M.; Lee, Y.-H.; Fan, L. T. Structural modification of lignocellulosics by pretreatments to enhance enzymatic hydrolysis. Biotechnol. Bioeng. 1983, 25, 157-172. 
(55) Ghose, T. K. Adv. Biochem. Eng. 1977, 7, 39.

(56) Ghose, T. K.; Das, K. In Advances in Biochemical Engineering; Springer-Verlag: Berlin, Germany, 1971; Vol. 1, p 55.

(57) Gilkes, N. R.; Kilburn, D. G.; Miller, R. C., J r.; Warren, R. A. J .; Sugiyama, J .; Chanzy, H.; Henrissat, B. Visualization of the adsorption of a bacterial endo- $\beta$-1,4-glucanase and its isolated cellulose-binding domain to crystalline cellulose. Int. J. Biol. Macromol. 1993, 15, 347-351.

(58) Glasser, W. G.; Ravindran, G.; J ain, R. K.; Samaranayake, G.; Todd, J . Comparative enzyme biodegradability of xylan, cellulose, and starch derivatives. Biotechnol. Prog. 1995, 11 $552-557$.

(59) Grethlein, H. E. The effect of pore size distribution on the rate of enzymatic hydrolysis of cellulosic substrates. Bio/ Technology 1985, 3, 155-160.

(60) Grethlein, H. E.; Allen, D. C.; Converse, A. O. A comparative study of the enzymatic hydrolysis of acid-pretreated white pine and mixed hardwood. Biotechnol. Bioeng. 1984, 26, 1498-1505.

(61) Halliwell, G.; Giffin, M. Nature and mode of action of the cellulolytic component $C_{1}$ of Trichoderma koningi i on native cellulose. Biochem. J. 1973, 135, 587-594.

(62) Halliwell, G.; Raiz, M. Interactions between components of the cellulase complex of Trichoderma koningi on native substrates. Arch. Mikrobiol. 1971, 78, 295-309.

(63) Hayashi, N.; Ishihara, M.; Shimizu, K. The features in enzymatic hydrolysis residues of highly crystalline native cellulose. Mokuzai Gakkaishi 1995, 41, 1132-1138.

(64) Henriksson, G. Structure, function and applications of cel lobi ose dehydrogenase from Phanerochaete chrysosporium; Ph.D. Thesis: Acta Universitatis Upsaliensis, Uppsala Swe den: 1995; p 53.

(65) Henrissat, B. A new cellulase family. Mol. Microbiol. 1997, 23, 848-849.

(66) Henrissat, B.; Driguez, H.; Viet, C.; Schülein, M. Synergism of cellulases from Trichoderma reesei in the degradation of cellulose. Bio/ Technol ogy 1985, 3, 722-726.

(67) Henrissat, B.; Vigny, B.; Buleon, A.; Perez, S. Possible adsorption sites of cellulases on crystalline cellulose. FEBS 1988, 231, 177-182.

(68) Hoshino, E.; Kanda, T.; Sasaki, Y.; N isizawa, K. Adsorption mode of exo- and endo-cellulases from I rpex lacteus (Polyporus tulipiferae) on cellulose with different crystallinities. J. Biochem. 1992, 111, 600-605.

(69) Hoshino, E.; Sasaki, Y.; Okazaki, M.; Nisizawa, K.; Kanda, T. Mode of action of exo- and endo-type cellulases from I rpex lacteus in the hydrolysis of cellulose with different crystallinities. J . Biochem. 1993, 114, 230-235.

(70) Ishikawa, A.; Okano, T.; Sugiyama, J . Fine structure and tensile properties of ramie fibres in the crystalline form of cellulose I, II, IIII and IVI. Polymer 1997, 38, 463-468.

(71) J ackson, L. S.; Heitmann, J .; J oyce, T. Enzymatic modifications of secondary fibre. Tappi J . 1993, 76, 147-154.

(72) J ackson, L. S.; Heitmann, J .; J oyce, T. Visualization of enzyme binding to secondary fibre silver-enhanced colloidal gold. Prog. Paper Recycl. 1994, 3, 32-41.

(73) Kibblewhite, R. P.; Clark, T. A. Enzymatic modification of radiata pine kraft fibre and handsheet properties. Appita 1996, 49, 390-396.

(74) Kim, D. W.; J eong, Y. K.; J ang, Y. H.; Lee, J . K. Adsorption characteristics of endo II and exo II purified from Trichoderma viride on microcrystalline celluloses with different surface area. Bulletin of the Korean Chemical Society 1995 16, 498-503.

(75) Kim, D. W.; J eong, Y. K.; J ang, Y. H.; Lee, J . K.; Kim, K. S.; Ryu, H. Kinetic mechanism of cellulose hydrolysis by endoglucanase I and exoglucanase II purified from Trichoderma viride Bull. Korean Chem. Soc. 1995, 16, 742-747.

(76) Kim, D. W.; Yang, J . H.; J eong, Y. K. Adsorption of cellulase from Trichoderma viride on microcrystalline cellulose. Appl. Microbiol. Biotechnol. 1988, 28, 148-154.

(77) Kim, D. W.; Yoon, Y. H.; J eong, Y. K.; Lee, J . K.; J ang, Y. $\mathrm{H}$. Effect of adsorption of endoglucanase on the degradation of microcrystalline cellulose. Bull. Korean Chem. Soc. 1995, $16,720-725$
(78) Kleman-Leyer, K.; Agosin, E.; Conner, A. H.; Kirk, T. K. Changes in molecular size distribution of cellulose during attack by white rot and brown rot fungi. Appl. Environ. Microbiol. 1992, 58, 1266-1270.

(79) Kleman-Leyer, K.; Gilkes, N. R.; Miller, R. C., J r.; Kirk, T. K. Changes in molecular size distribution of insoluble celluloses by the action of recombinant Cellulomonas fimi cellulases. Biochem. J . 1994, 302, 463-469.

(80) Kleman-Leyer, K. M.; Kirk, T. K. Three native cellulosedepolymerizing endoglucanases from solid-substrate cultures of the brown rot fungus Meruliporia (Serpula) incrassata. Appl. Environ. Microbiol. 1994, 60, 2839-2845.

(81) Kleman-Leyer, K. M.; Siika-aho, M.; Teeri, T. T.; Kirk, T. $\mathrm{K}$. The cellulases endoglucanase I and cellobiohydrolase II of Trichoderma reesei act synergistically to solubilize native cotton cellulose but not to decrease its molecular size. Appl. Environ. Microbiol. 1996, 62, 2883-2887.

(82) Klyosov, A. A. Trends in biochemistry and enzymology of cellulose degradation. Biochem. J . 1990, 29, 10577-10585.

(83) Klyosov, A. A.; Mitkevich, O. V.; Sinitsyn, A. P. Role of the activity and adsorption of cellulases in the efficiency of the enzymatic hydrolysis of amorphous and crystal line cellulose Biochemistry 1986, 25, 540-542.

(84) Kondo, T. The relationship between intramolecular hydrogen bonds and certain physical properties of regioselectively substituted cellulose derivatives. J. Polym. Sci., Part B: Polym. Phys. 1997, 35, 717-723.

(85) Kremer, S. M.; Wood, P. M. Continuous monitoring of cellulose oxidation by cellobiose oxidase from Phanerochaete chrysosporium. FEMS Microbiol. Lett. 1992, 92, 187-192.

(86) Ladisch, M. R.; Lin, K. W.; Voloch, M.; Tsao, G. T. Process considerations in the enzymatic hydrolysis of biomass. Enzyme Microb. Technol. 1983, 5.

(87) Laivins, G. V.; Scallan, A. M. The influence of drying and beating on the swelling of fines. J. Pulp Pap. Sci. 1996, 22, J $178-184$

(88) Lee, D.; Yu, A. H. C.; Wong, K. K. Y.; Saddler, J . N. Evaluation of the enzymatic susceptibility of cellulosic substrates using specific hydrolysis rates and enzyme adsorption Appl. Biochem. Biotechnol. 1994, 45/ 46, 407-415.

(89) Lee, I.; Evans, B. R.; Lane, L. M.; Woodward, J . Substrate enzyme interactions in cellulase systems. Bioresour. Technol. 1996, 58, 163-169.

(90) Lee, N. E.; Lima, M.; Woodward, J . Biochim. Biophys. Acta 1988, 967, 437-440.

(91) Lee, S. B.; Kim, I. H. Structural properties of cellulose and cellulase reaction mechanisms. Bi otechnol. Bioeng. 1983, 25, 33-51.

(92) Lee, S. B.; Shin, H. S.; Ryu, D. D. Y. Adsorption of cellulase on cellulose: Effect of physicochemical properties of cellulose on adsoption and rate of hydrolysis. Biotechnol. Bioeng. 1982, 24, 2137-2153.

(93) Lenz, J .; Schurz, J .; Wrentschur, E. The length of the crystalline domains in fibres of regenerated cellulose. Determination of the crystallite length of cellulose II by means of wide-angle X-ray diffraction and transmission electron microscopy. Holzforschung 1988, 42, 117-122.

(94) Liu, W.; Madsen, N. B.; Braun, C.; Withers, S. G. Reassessment of the catalytic mechanism of glycogen debranching enzyme. Biochemistry 1991, 30, 1419-1424.

(95) Macarrón, R.; Henrissat, B.; Claeyssens, M. Family a cellulases - two essential tryptophan residues in endoglucanase III from Trichoderma reesei. Biochim. Biophys. Acta 1995, 1245, 187-190.

(96) Maekawa, E. On an available pretreatment for the enzymatic saccharification of lignocel lul osic materials. Wood Sci. Technol. 1996, 30, 133-139.

(97) Maglione, G.; Matsushita, O.; Russell, J . B.; Wilson, D. B. Properties of a genetically reconstructed Prevotel la sunimi cola endoglucanase. Appl. Environ. Microbiol. 1992, 58, 35933597.

(98) Mandels, M.; Reese, E. T. Dev. Ind. Microbiol. 1964, 5 , 5-16.

(99) Mansfield, S. D.; de J ong, E.; Saddler, J. N. Cellobiose dehydrogenase, an active agent in cellul ose depolymerization. Appl. Environ. Microbiol. 1997, 63, 3804-3809. 
(100) Mansfield, S. D.; de J ong, E.; Stephens, R. S.; Saddler, J . N. Physical characterization of enzymatically modified kraft pulp fibres. J . Biotechnol. 1997, 57, 205-216.

(101) Mansfield, S. D.; Dickson, A. R.; Saddler, J . N . I mproving paper properties by a selective enzymatic treatment of coarse pulp fibres; Proceedings of 7th International Conference on Biotechnology in the Pulp and Paper Industry; CPPA: Vancouver, BC, 1998; Vol. 1, pp 189-192.

(102) Mansfield, S. D.; Saake, B.; Gübitz, G.; de J ong, E.; Puls, J .; Saddler, J . N. I dentification, purification and characterization of the predominant endoglucanases from two brown-rot fungal strains of Gloeophyllum. In Carbohydrases from Trichoderma reese and Other Microorganisms: Structures, Biochemistry, Genetics and Applications; Claeyssens, M., Nerinckx, W., Piens, K., Eds.; The Royal Society of Chemistry: Cambridge, U.K., 1998; pp 227-244.

(103) Mansfield, S. D.; Saddler, J . N.; Gübitz, G. M. Characterization of endoglucanases from the brown rot fungi Gloeophyllum sepiarium and Gloeophyllum trabeum. Enzyme Microb. Technol. 1998, 23, 133-140.

(104) Mansfield, S. D.; Wong, K. K. Y.; de J ong, E.; Saddler, J . N. Modification of Douglas-fir mechanical and kraft pulps by enzyme treatment. Tappi J . 1996, 79, 125-132.

(105) Martinez, J . M.; Reguant, J .; Montero, M. A.; Montane, D.; Salvado, J .; Farriol, X. Hydrolytic pretreatment of softwood and almond shells - degree of polymerization and enzymatic digestibility of the cellulose fraction. Ind. Eng. Chem. Res. 1997, 36, 688-696.

(106) Marx-Figini, M.; Finetti, M.; von Ellenrieder, G. Enzymatic degradation of cotton cellulose by separated endo- and exocellulase. Cellul. Chem. Technol. 1997, 31, 155-162.

(107) Mooney, C. A.; Mansfield, S. D.; Touhy, M. G.; Saddler, $\mathrm{J}$. N. The effect of initial pore volume and lignin content on the enzymatic hydrolysis of softwoods. Bioresour. Technol. 1998, 64, 113-119.

(108) Morpeth, F. F. Cellobiose oxidoreductases. In Chemistry and Biochemistry of Flavoproteins; Müller, F., Ed.; CRC Press: Boca Raton, FL, 1991; Vol. 1, pp 337-348.

(109) Nazhad, M. M.; Ramos, L. P.; Paszner, L.; Saddler, J . N. Structural constraints affecting the initial enzymatic hydrolysis of recycled paper. EnzymeM icrob. Technol. 1995, 17, 6874.

(110) Nelson, R.; Oliver, D. W. Study of cellulose structure and its relation to reactivity. J . Polym. Sci. 1971, 36, 305-320.

(111) Neuman, R. P.; Walker, L. P. Solute exclusion from cellulose in packed columns: Experimental investigation and pore volume measurements. Biotechnol. Bioeng. 1992, 40, $218-225$.

(112) Nidetzky, B.; Claeyssens, M. Specific quantification of Trichoderma reese cellulases in reconstituted mixtures and its application to cellulase-cellulose binding studies. Biotechnol. Bioeng. 1994, 44, 961-966.

(113) Nidetzky, B.; Hayn, M.; Macarron, R.; Steiner, W. Synergism of Trichoderma reesei cellulases while degrading different celluloses. Biotechnol. L ett. 1993, 15, 71-76.

(114) Nidetzky, B.; Steiner, W.; Claeyssens, M. Cellulose hydrolysis by the cellulases from Trichoderma reesei: adsorptions of two cellobiohydrolases, two endocellulases and their core proteins on filter paper and their relation to hydrolysis. Biochem. J . 1994, 303, 817-823.

(115) Nidetzky, B.; Steiner, W.; Hayn, M.; Claeyssens, M. Cellulose hydrolysis by the cellulases from Trichoderma reesei: a new model for synergistic interaction. Biochem. J . 1994, 298, 705-710.

(116) Nidetzky, B.; Zachariae, W.; Gercken, G.; Hayn, M.; Steiner, W. Hydrolysis of cellooligosaccharides by Trichoderma reesei cellobiohydrolases: Experimental data and kinetic modeling. Enzyme Microb. Technol. 1994, 16, 43-52.

(117) Nieves, R. A.; Ellis, R. P.; Todd, R. J .; J ohnson, T.J . A.; Grohmann, K.; Himmel, M. E. Visualization of Trichoderma reese cellobiohydrolase I and endoglucanase I on Aspen cellulose by using monoclonal antibody-colloidal gold conjugates. Appl. Environ. Microbiol. 1991, 57, 3163-3170.

(118) Nisizawa, K. J . Mode of action of cellulases. J . Ferment. Technol. 1973, 51, 267-304.
(119) Nisizawa, T.; Suzuki, J .; Nisizawa, K. J . Ferment. Technol. 1966, 44, 275.

(120) Ooshima, H.; Burns, D. S.; Converse, A. O. Adsorption of cellulase from Trichoderma reesei on cellulose and lignacious residue in wood pretreated by dilute sulfuric acid with explosive decompression. Biotechnol. Bioeng. 1990, 36, 446452.

(121) Ooshima, H.; Kurakake, M.; Kato, J .; Harano, Y. Enzymatic activity of cellulase adsorbed on cellulose and its change during hydrolysis. Appl. Biochem. Biotechnol. 1991, 31, 253266.

(122) Ooshima, H.; Sakata, M.; Harano, Y. Adsorption of cellulase from Trichoderma viride on cellulose. Biotechnol. Bioeng. 1983, 25, 3103-3114.

(123) Parajo, J . C.; Alonso, J . L.; Santos, V. Delignification and swelling of eucalpytus wood ahead of enzymatic hydrolysis of the cellulosic fraction. Proc. Biochem. 1995, 30, 537-545.

(124) Pere, J .; Siika-aho, M.; Buchert, J .; Viikari, L. Effects of purified Trichoderma reesei cellulases on the fibre properties of kraft pulp. Tappi J . 1995, 78, 71-78.

(125) Phillip, B.; Dan, D. C.; Fink, H. P. Acid and enzymatic hydrolysis on cellulose in relation to its physical. Proceedings of the International Symposium on Wood and Pulping Chemistry: Stockholm, Sweden, 1981; Vol. 4, pp 79-83.

(126) Pilon, L.; Desrochers, M.; J urasek, L.; Neumann, P. J . Increasing water retention of mechanical pulps by biological treatment. Tappi J . 1982, 65, 93-96.

(127) Puls, J .; Stork, G. Potential uses of enzymes in the pulp and paper industry. Wochenbl. Papierfabr. 1995, 123, 926930.

(128) Puls, J .; Stork, J .; Schuseil, J. Reactions of isolated cellulases, hemicellulases and ligninases with fibrous materials and isolated components of wood. Papier 1993, 47, 719728.

(129) Puls, J .; Wood, T. M. The degradation pattern of cellulose by extracellular cellulases of aerobic and anaerobic microorganisms. Bioresour. Technol. 1991, 36, 15-19.

(130) Puri, V. P. Effect of crystallinity and degree of polymerization of cellul ose on enzymatic saccharification. Biotechnol . Bioeng. 1984, 26, 1219-1222.

(131) Ramos, L. P.; Breuil, C.; Saddler, J . N. Comparison of steam pretreatment of Eucalyptus, Aspen and Spruce wood chips and their enzymatic hydrolysis. Appl. Biochem. Biotechnol. 1992, 34/ 35, 37-47.

(132) Ramos, L. P.; Nazhad, M. M.; Saddler, J . N. Effect of enzymatic hydrolysis on the morphology and fine structure of pretreated cellulosic residues. Enzyme Microb. Technol. 1993, 15, 821-831.

(133) Ramos, L. P.; Saddler, J. N. Bioconversion of wood residues. Mechanisms involved in pretreating and hydrolyzing lignocellulosic materials. In Enzymatic conversion of biomass for fuels production; Himmel, M. E., Baker, J . O., Overend, R. P., Eds.; American Chemical Society, 1994; Vol. 566, pp 326-341.

(134) Rao, M.; Mishra, A. C. Glucohydrolase from Penicillium funicul osum. Appl. Microbiol. Biotechnol. 1989, 30, 130-134.

(135) Reese, E. T. A microbiological progress report: enzymatic hydrolysis of cellulose. Appl. Microbiol. 1956, 4, 39-45.

(136) Reese, E. T.; Segal, L.; Tripp, V. W. Text. Res. J . 1957, 27, 629

(137) Reese, E. T.; Siu, R. G. H.; Levinson, H. S. Biological degradation of soluble derivatives. J. Bacteriol. 1950, 59, 485-497.

(138) Reidel: K.; Ritter, J .; Bronnrnmeier, K. Synergistic interaction of the Clostridium stercorarium cellulases Avicelase I (Cel Z) and Avicelase II (CelY) in the degradation of microcrystallin cellulose. FEMS Microb. Lett. 1997, 147, 239243.

(139) Reinikainen, T.; Ruohonen, L.; Nevanen, T.; Laaksonen, L.; Kraulis, P.; J ones, T. A.; Knowles, J . K. C.; Teeri, T. T. Investigation of the function of mutated cellulose binding domains of Trichoderma reesei cellobiohydrolase I. Proteins: Struct., Funct., Genet. 1992, 14, 475.

(140) Reinikainen, T.; Takkinen, K.; Teeri, T. T. Comparison of the adsorption properties of a single-chain antibody frag- 
ment fused to a fungal or bacterial cellulose-binding domain. Enzyme Microb. Technol. 1997, 20, 143-149.

(141) Rivers, D. B.; Emert, G. H. Factors affecting the enzymatic hydrolysis of municipal solid waste components. Biotechnol. Bioeng. 1988, 26, 278-281.

(142) Roberts, J . C. The Chemistry of Paper; The Royal Society of Chemistry: Cambridge, U.K., 1996.

(143) Ruel, K.; Barnoud, F.; J oseleau, J .-P.; J ohnsrud, S. C.; Eriksson, K.-E. Ultrastructural aspects of birch wood degradation by Phanerochaete chrysosporium and two of its cellulase deficient mutants. Holzforschung 1986, 40, 5-9.

(144) Saake, B.; Horner, S.; Puls, J . Progress in the enzymatic hydrolysis of cellulose derivatives. In Recent Advances in Cellulose Derivatives; Heinze, T., Glasser, W. G., Eds.; American Chemical Society: Washington, D.C., 1997.

(145) Saddler, J . N. Factors limiting the efficiency of cellulase enzymes. Microbiol. Sci. 1986, 3, 84-87.

(146) Samejima, M. Research trend in cellulase and cellulose biodegradation. Mokuzai Gakkaishi 1996, 42, 811-816.

(147) Sarko, A.; Muggli, R. Packing analysis of carbohydrates and polysaccharides. III. Valonia cellulose and cellulose II. Macromol ecules 1974, 7, 486-494.

(148) Sasaki, T.; Tanaka, T.; Nanbu, N.; Sato, Y.; Kainuma, K. Correlation between $\mathrm{X}$-ray diffraction measurements of celIulose crystalline structure and the susceptibility to microbial cellulase. Biotechnol. Bioeng. 1979, 21, 1031-1042.

(149) Sawada, I.; Kuwahara, M.; Nakamura, Y.; Suda, H. Effect of a process of explosion for the effective utilization of biomass. Int. Chem. Eng. 1987, 27, 686-693.

(150) Sawada, T.; Nakamura, Y.; Kobayashi, F.; Kuwahara, M.; Watanabe, T. Effects of fungal pretreatment and steam explosion pretreatment on enzymatic saccharification of plant biomass. Biotechnol. Bioeng. 1995, 48, 719-724.

(151) Shewale, I. G.; Sadana, J . C. Enzymatic hydrolysis of cellulosic materials by Sclerotium rolfsii culture filtrate for sugar production. Can. J . Microbiol. 1979, 25, 773.

(152) Sineiro, J .; Dominguez, H.; Nunez, M. J .; Lema, J . M. Hydrolysis of microcrystalline cellul ose by cellul olytic complex of Trichoderma reesei in low-moisture media. Enzyme Microb. Technol. 1995, 17, 809-815.

(153) Sinitsyn, A. P.; Gusakov, A. V.; Vlasenko, E. Y. Effect of structural and physicochemical features of cellulosic substrates on the efficiency of enzymatic hydrolysis. Appl. Biochem. Biotechnol. 1991, 30, 43-59.

(154) Sinnott, M. L. Catalytic mechanisms of enzymic glycosyl transfer. Chem. Rev. 1990, 90, 1171-1202.

(155) Sjöström, E. Wood Chemistry: Fundamentals and Applications, 2nd ed.; Academic Press: London, U.K., 1993.

(156) Sprey, B.; Bochem, H. P. Effect of endoglucanase and cellobiohydrolase from Trichoderma reesei on cellulose microfibril structure. FEMS Microbiol. Lett. 1992, 97, 113-117.

(157) Sprey, B.; Bochem, H. P. Formation of cross-fractures in cellulose microfibril structure by an endoglucanase-cellobiohydrolase complex from Trichodema reesei. FEMS Microbiol. Lett. 1993, 106, 239-2434.

(158) Ståhl berg, J .; J ohansson, G.; Pettersson, G. Trichoderma reese has no true exo-cellulase: all intact and truncated cellulases produce new reducing end groups on cellulose. Biochim. Biophys. Acta 1993, 1157, 107-113.

(159) Stålbrand, H.; Mansfield, S. D.; Saddler, J . N.; Kilburn, D. G.; Warren, R. A. J .; Gilkes, N. R. Analysis of molecular size distributions of cellulose molecules during hydrolysis of cellul ose by recombinant Cedlul omonas fi mi $\beta$-1,4-Glucanases. Appl. Environ. Microbiol. 1998, 64, 2374-2379.

(160) Stone, J . E.; Scallan, A. M. The effect of component removal upon porous structure of the cell wall of wood. Part III. A comparison between sulphite and kraft processes. Pulp Pap. Mag. Can. 1969, 69, T219-241.

(161) Stone, J . E.; Scallan, A. M.; Donefer, E.; Ahlgren, E. Digestibility as a simple finction of a molecule of a similar size to a cellulase enzyme. Adv. Chem. Ser. 1969, 95, 219241.

(162) Stork, G.; Pereira, H.; Wood, T.; Düsterhöft, E.; Toft, A.; Puls, J . U pgrading recycled pulps using enzymatic treatment. Tappi J . 1995, 78, 79-88.
(163) Sutcliffe, R.; Saddler, J . N. The Role of lignin in the adsorption of cellulases during enzymatic treatment of lignocellulosic material. Biotechnol. Bioeng. 1986, 17, 749-762.

(164) Tan, L. U. L.; Yu, E. K. C.; Mayers, P.; Saddler, J . N. Column cellulose hydrolysis reactor: cellulase adsorption profile. Appl. Microbiol. Biotechnol. 1986, 25, 256-261.

(165) Tanahashi, M. Characterisation and degredation mechanisms of wood components by steam explosion and utilisation of exploded wood. Wood Res. 1990, 77, 49-117.

(166) Tanahashi, M.; Goto, T.; Horii, F.; Hirai, A.; Higuchi, T. Characterization of steam-exploded wood III. Transformation of cellulose crystals and changes of crystallinity. Mokuzai Gakkaishi 1989, 35, 654-662.

(167) Tanaka, M.; I kesaka, M.; Matsuno, R.; Converse, A. O. Effect of pore size in substrate and diffusion of enzyme on hydrolysis of cellulosic materials with cellulases. Biotechnol. Bioeng. 1988, 32, 698-706.

(168) Tarkow, H.; Feist, W. C. A mechanism for improving the digestibility of lignocellulosic materials with dilute al kali and liquid ammonia. In Cellulases and their applications; Gould, R. F., Eds.; American Chemical Society: Washington, DC 1969; Vol. Advances in Chemistry Series 95, pp 197-218.

(169) Teeri, T. T.; Reinikainen, T.; Ruohonen, L.; J ones, T. A.; J. K. C., K. Domain function in Trichoderma reesei cellobiohydrolases. J . Biotechnol. 1992, 21, 169-176.

(170) Thompson, D. N.; Chen, H. C.; Grethlein, H. E. Comparison of pretreatment methods on the basis of available surface area. Bioresour. Technol. 1992, 39, 155-163.

(171) Thompson, D. N.; Chen, H.-C.; Grethlein, H. E. Changes in the rate of enzymatic hydrolysis and surface area available to cellulase with pretreatment methods. In Biotechnol ogy in Pulp and Paper Manufacture: Applications and Fundamental Investigations; Kirk, T. K., Chang, H.-M., Eds.; ButterworthHeinemann: Boston, MA, 1990; pp 329-338.

(172) Tjerneld, F. Enzyme-catalyzed hydrolysis and recycling in cellul ose bioconversion. Methods Enzymol . 1994, 228, 549558.

(173) Tomme, P.; Driver, D. P.; Amandoron, E. A.; Miller, R. C.; Antony, R.; Warren, J .; Kilburn, D. G. Comparison of a fungal (family I) and bacterial (family II) cellulose-binding domain. J . Bacteriol. 1995, 177, 4356-4363.

(174) Tomme, P.; Kwan, E.; Gilkes, N. R.; Kilburn, D. G. Warren, R. A. J . Characterization of CenC, an enzyme from Cellulomonas fimi with both endo- and exoglucanase activities. J. Bacteriol. 1996, 178, 4216-4223.

(175) Tomme, P.; Van Tilbeurgh, H.; Pettersson, G.; Van Damme, J .; Vandekerckhove, J .; Knowles, J .; Teeri, T.; Claeyssens, M. Studies of the cellulolytic system of Trichoderma reese QM 9414. Analysis of domain function in two cellobiohydrolases by limited proteolysis. Eur. J . Biochem. 1988, 170, 575-581.

(176) Tomme, P.; Warren, A. J .; Gilkes, N. R. Cellulose hydrolysis by bacteria and fungi. Adv. Microb. Physiol. 1995, 37, 1-81.

(177) Ucar, G.; Fenger, D. Characterisation of the acid pretreatment for the enzymatic hydrolysis of wood. Holzforschung 1988, 42, 141-148.

(178) Walseth, C. S. The influence of the fine structure of cellulose on the action of cellulases. Tappi 1952, 35, 233236.

(179) Ward, O. P.; Moo-Y oung, M. Enzymatic degradation of cell wall and related plant polysaccharides. CRC Crit. Rev. Bi otechnol. 1989, 8, 237-274.

(180) Warren, R. A. J . Microbial hydrolysis of polysaccharides. Annu. Rev. Microbiol. 1996, 50, 183-212.

(181) Weimer, P.J .; Lopez-Guisa, J . M.; French, A. D. Effect of cellulose fine structure on kinetics of its digestion by mixed ruminal microorganisms in vitro. Appl. Environ. Microbiol. 1990, 56, 2421-2429.

(182) Weimer, P. J .; Weston, W. M. Relationship between the fine structure of native cellulose and cellulose degradability by the cellulase complexes of Trichoderma reese and Clostridium thermocel lum. Bi otechnol. Bi oeng. 1985, 27, 1540-1547.

(183) White, A. R.; Brown, M., J r. Enzymatic hydrolysis of cellulose: Visual characterization of the process. Proc. Natl. Acad. Sci. U.S.A. 1981, 78, 1047-1051. 
(184) Wilson, D. B.; Spezio, M.; Irwin, D.; Karplus, A.; Taylor, $\mathrm{J}$. Comparison of enzymes catalyzing the hydrolysis of insoluble polysaccharides. In Enzymatic Degredation of Insoluble Carbohydrates; Saddler, J. N., Penner, M., Eds.; American Chemical Society: Washington, D. C., 1995.

(185) Withers, S. G.; Dombroski, D.; Berven, L. A.; Kilburn, D. G.; Miller, R. C. J .; Warren, R. A. J .; Gilkes, N. R. Direct ${ }^{1} \mathrm{H}$ N. M. R. determination of the stereochemical course of hydrolyses catalysed by glucanase components of the cellulase complex. Biochem. Biophys. Res. Commun. 1986, 139, 487494.

(186) Withers, S. G.; Tull, D.; Gebler, J .; Braun, C.; Aebersold, R.; Wang, Q.; Warren, T.; Kilburn, D.; Gilkes, N. Mechanistic studies on cellulases. In Proceedings of the second TRICEL symposium on Trichoderma reesei cellulases and other hydrolases; Suominen, P., Reinikainen, T., Eds.; Espoo: Finland, 1993; pp 117-123.

(187) Wong, K. K. Y.; Deverell, K. F.; Mackie, K. L.; Clark, T. A.; Donaldson, L. A. The relationship between fibre porosity and cellulose digestibility in steam-exploded Pinus radiata. Biotechnol. Bioeng. 1988, 31, 447-456.

(188) Wood, T. M. Cellulolytic enzymes system of Trichoderma koningii. Separation of components attacking native cotton. Biochem. J . 1968, 109, 217-229.

(189) Wood, T. M. Fungal Cellulases. In Biosynthesis and Biodegradation of Cellul oseand Cellul osi c Materials; Weimer, P. J ., Hagler, C. A., Eds.; Marcel Dekker: New York, 1989; pp $491-534$.

(190) Wood, T. M. F ungal cellulases. Biochem. Soc. Trans. 1992, 20, 46-53.

(191) Wood, T. M.; Garcia-Campayo, V. Enzymology of cellulose degradation. Biodegradation 1990, 1, 147-161.

(192) Wood, T. M.; McCrae, S. I. The cellulase of Penicillium pinophilum. Synergism between enzyme components in solubilizing cellulose with special reference to the involvement of two immunol ogically distinct cellobiohydrol ases. Biochem. J. 1986, 234, 93-99.

(193) Wood, T. M.; McCrae, S. I. The mechanism of cellulase action with particular reference to the $C_{1}$ component. In Proceedings of the Symposium on Bioconversion of Cellul osic Substances into Energy, Chemicals and Microbial Protein; Ghose, T., Ed.; New Delhi, 1978; pp 114-141.

(194) Wood, T. M.; M cCrae, S. I. Purification and properties of a cellobiohydrolase from Penicillium pi nophilum. Carbohydr. Res. 1986, 148, 331-344.

(195) Wood, T. M.; McCrae, S. I. The purification and properties of the $\mathrm{C}_{1}$ component of Trichoderma koningii cellulase. Biochem. J . 1972, 128, 1183-1192.

(196) Wood, T. M.; McCrae, S. I. Synergism between enzymes involved in the solubilization of native cellulose. Adv. Chem. Ser. 1979, 181, 181-209.

(197) Wood, T. M.; McCrae, S. I.; Bhat, K. M. The mechanism of fungal cellulase action. Synergism between enzyme components of Penicillium pinophilum cellulase in solubilizing hydrogen-bond ordered cellulose. Biochem. J . 1989, 260, 3743.

(198) Woodward, J . Synergism in cellulase systems. Bioresour. Technol. 1991, 36, 67-75.

(199) Yu, A. H. C.; Saddler, J. N. Identification of essential cellulase components in the hydrolysis of a steam-exploded birch substrate. Biotechnol. Appl. Biochem. 1995, 21, 185202.

(200) Zadrazil, F.; Puniya, A. K. Studies on the effect of particle size on solid-state fermentation of sugarcane bagasse into animal feed using whiterot fungi. Bioresour. Technol. 1995, $54,85-87$

Accepted J une 28, 1999.

BP9900864 